Vol. 1, No. 1 (2020): 19-34

http://journalsttcipanas.ac.id/index.php/NPTRS/

p-ISSN 2722-9726, e-ISSN 2722-9718

Published by Sekolah Tinggi Teologi Cipanas (Cipanas Theological Seminary)

\title{
Peranan Tes Hasil Belajar Dalam Meningkatkan Motivasi Peserta Didik dalam Belajar Agama
}

\author{
Yudha Nata Saputra \\ Sekolah Tinggi Teologi Cipanas \\ Email: yudhanata99@gmail.com
}

\begin{abstract}
Religious education plays an important role in the national education system in Indonesia so that religious education becomes compulsory to be taught in all types, lines and levels of education in Indonesia. Even though it is important, the quality of religious education in Indonesia is not yet optimal, this is indicated by the still low motivation of students to learn in studying religion. Meanwhile, learning outcomes tess play an important role in obtaining a picture of the quality of education. The purpose of writing this article is intended to examine the things that need to be considered in preparing a good learning achievement tes, knowing how the learning achievement tes can increase student motivation in religious learning. The learning achievement tes carried out is important to increase student motivation in studying religion which will have an impact on the quality of education in Indonesia. The results of the study, showed that learning outcomes tess will provide benefits if done by paying attention to the principles of tes preparation. Then a tes of learning outcomes carried out regularly will be able to motivate students in religious learning by providing short-term learning goals for students
\end{abstract}

Keywords: tes, learning, religion, student, motivation.

\begin{abstract}
Abstrak
Pendidikan agama memegang peranan penting dalam sistem pendidikan nasional di Indonesia sehingga pelajaran agama menjadi wajib untuk diajarkan dalam setiap jenis, jalur dan jenjang pendidikan di Indonesia. Meskipun penting, namun kualitas pendidikan agama di Indonesia belum optimal, hal ini ditandai dengan masih rendahnya motivasi belajar peserta didik dalam belajar agama. Sementara itu, tes hasil belajar memegang peranan yang penting dalam memperoleh gambaran tentang kualitas pendidikan. Tujuan penulisan artikel ini dimaksudkan untuk mengkaji hal-hal yang perlu diperhatikan dalam penyusunan sebuah tes hasil belajar yang baik, mengetahui bagaimana tes hasil belajar dapat meningkatkan motivasi peserta didik dalam belajar agama. Tes hasil belajar yang dilaksanakan penting untuk meningkatkan motivasi peserta didik dalam belajar agama yang akan berdampak terhadap mutu pendidikan di Indonesia. Hasil kajian, menunjukkan bahwa tes hasil belajar akan memberikan manfaat jika dilakukan dengan memperhatikan prinsip-prinsip penyusunan tes. Kemudian tes hasil belajar yang dilaksanakan secara teratur akan dapat memotivasi peserta didik dalam belajar agama dengan menyediakan tujuan-tujuan belajar jangka pendek untuk peserta didik.
\end{abstract}

Kata kunci: tes, belajar, agama, peserta didik, motivasi

\section{Pendahuluan}

Pendidikan agama memegang peranan penting dalam sistem pendidikan nasional di Indonesia. Tujuan pendidikan nasional di Indonesia bukan saja mengembangkan potensi peserta didik agar menjadi manusia yang berilmu tetapi juga mengem- 
bangkan potensi peserta didik agar menjadi manusia yang beriman dan bertakwa kepada Tuhan Yang Maha Esa dan berakhlak mulia. ${ }^{1}$ Dalam Peraturan Pemerintah. No. 57 Tahun 2017, mengatakan bahwa fungsi pendidikan agama bukan hanya menjadikan manusia Indonesia beriman dan bertakwa kepada Tuhan Yang Maha Esa, dan berakhlak mulia tetapi sekaligus mampu menjaga kedamaian dan kerukunan dalam kehidupan beragama di Indonesia. ${ }^{2}$ Dalam peraturan pemerintah ini, tujuan pendidikan agama diperjelas bukan hanya menjadikan manusia beriman dan bertakwa kepada Tuhan Yang Maha Esa saja namun mampu menjaga hubungan yang baik dalam kehidupan beragama, baik dalam lingkup internal agama maupun hubungan antaragama.

Begitu pentingnya pendidikan agama dalam sistem pendidikan nasional di Indonesia, menjadikan pelajaran agama menjadi wajib untuk diajarkan dalam setiap jenis, jalur dan jenjang pendidikan di Indonesia. Sedemikian pentingnya pendidikan agama di Indonesia tentu menuntut kualitas pendidikan agama yang semakin baik, namun pada kenyataannya tampaknya kualitas pendidikan agama di Indonesia hingga saat ini masih dalam kondisi yang belum terlalu menggembirakan, hal ini dapat dilihat dari hasil kajian perilaku keberagamaan peserta didik di sekolah yang dilakukan oleh Puslitbang Pendidikan Agama dan Keagamaan Badan Litbang dan Diklat Kementerian Agama bekerja sama dengan INCIS (Indonesian Institute for Civil) Jakarta di 201 Sekolah Menengah Umum (SMU) dan Madrasah Aliyah (MA) yang tersebar di Pulau Jawa dan Sulawesi pada November 2011, menemukan bahwa skor kecenderungan sikap dan perilaku toleran peserta didik sebesar $71,1 \%$ dan skor yang menunjukkan kecenderungan sangat toleran adalah $11,1 \%$ tetapi kecenderungan yang mengarah pada sikap intoleran sejumlah $17,3 \% .^{3}$ Demikian pula dalam laporan tahunan kehidupan beragama 2018, mencatat peristiwa teror yang dilakukan oleh seorang pelajar dengan pedang kepada jemaat yang sedang mengikuti kegiatan ibadah Misa Pagi di Gereja Santa Lidwina Bedog, Sleman, Yogyakarta, pada Minggu 11 Februari 2018. ${ }^{4}$ Kasus serupa, terjadi pada tanggal 28 Agustus 2016 di Gereja Santo Yosep, Medan, seorang remaja berusia 18 tahun yang tercatat sebagai peserta didik SMA mengacungkan kapada

\footnotetext{
${ }^{1}$ Indonesia, Undang-Undang Republik Indonesia Nomor 20 Tahun 2003 Tentang Sistem Pendidikan Nasional, 2003.

${ }^{2}$ Indonesia, Peraturan Pemerintah Nomor 55 Tahun 2007 Tentang Pendidikan Agama Dan Pendidikan Keagamaan, 2007.

${ }^{3}$ Rohmat Suprapto and S Ag, "Deradikalisasi Agama Melalui Pendidikan MultikulturalInklusivisme" 15, no. 2 (2011): 89-105.

${ }^{4}$ Indonesia, Laporan Tahunan Kehidupan Keagamaan 2018 (Jakarta, 2018).
} 
Pastor Albert S. Pandiangan sambil membawa bom rakitan pada saat kegiatan Misa Kudus. ${ }^{5}$ Padahal pendidikan agama diberikan bukan untuk memusuhi umat yang berbeda iman, religious education should show that the common enemy of religion is not people of different faiths, but poverty, corruption, violence, ignorance, and the like, and they have to stand together to fight against these true enemies. ${ }^{6}$

Rendahnya kualitas pendidikan agama di Indonesia dapat terjadi salah satunya karena masih rendahnya motivasi belajar para peserta didik, karena mereka menganggap bahwa mereka merasa tidak perlu belajar, karena menurut mereka belajar dan tidak belajar sama saja. Pandangan seperti ini didukung pula oleh sistem penilaian yang belum berjalan sebagaimana mestinya, hal ini dapat kita lihat bahwa pada saat ujian naik kelas, peserta didik yang prestasinya baik dan buruk sama-sama naik kelas atau saat ujian akhir peserta didik yang berprestasi baik dan buruk sama-sama lulus. Hal ini juga terjadi karena adanya kebiasaan sebagian pendidik untuk mengatrol nilai, peserta didik yang nilainya 3 dikatrol jadi 5 atau yang dapat 5 dinaikkan jadi 7, peserta didik yang seharusnya tidak lulus, diluluskan juga. "Nilai hasil belajar peserta didik yang belum maksimal juga dapat disebabkan lemahnya kualitas pembelajaran."7 Keadaan seperti inilah yang tampaknya semakin memperkuat anggapan bahwa belajar dan tidak belajar sama saja, akibatnya motivasi belajar peserta didik menjadi rendah. "Motivasi belajar peserta didik yang rendah dapat berdampak pada proses dan hasil belajar peserta didik yang tidak meningkat dengan baik, bahkan sangat menurun." ${ }^{\prime 8}$ Dalam penelitiannya Rizki Permatasari mengemukakan bahwa rendahnya motivasi peserta didik dalam belajar agama dapat dilihat dari prestasi belajar yang tidak maksimal, yang dilihat dari nilai rata-rata ulangan harian yang masih di bawah standar ketuntasan. ${ }^{9}$

Selanjutnya dalam upaya memperoleh sumber daya manusia yang berkualitas, maka dalam sebuah sistem pendidikan diperlukan suatu alat evaluasi yang dapat meng-

\footnotetext{
${ }^{5}$ Suprapto and Ag, "Deradikalisasi Agama Melalui Pendidikan Multikultural-Inklusivisme."

${ }^{6}$ Achmad Asrori, "CONTEMPORARY RELIGIOUS EDUCATION MODEL ON THE CHALLENGE OF INDONESIAN MULTICULTURALISM," JOURNAL OF INDONESIAN ISLAM 10 (2016): 2 .

${ }^{7}$ Bekti Wulandari and Herman Dwi Surjono, "Pengaruh Problem-Based Learning Terhadap Hasil Belajar Ditinjau Dari Motivasi Belajar PLC Di SMK," Jurnal Pendidikan Vokasi 3, no. 2 (2013): $178-191$.

${ }^{8}$ Iik Faiqotul Ulya and Riana Irawati, "Peningkatan Kemampuan Koneksi Matematis Dan Motivasi Belajar Siswa Menggunakan Pendekatan Kontekstual,” Pena Ilmiah 1, no. 1 (2016): 121-130.

${ }^{9}$ Rizki Permatasari, "Faktor-Faktor Penyebab Rendahnya Motivasi Belajar Peserta Didik Pada Mata Pelajaran Pendidikan Agama Islam Di SMP Guna Dharma Bandar Lampung” (UIN Raden Intan Bandar Lampung, 2018).
}

The New Perspective in Theology and Religious Studies, Vol. 1, No. 1, 2020 - 21 
gambarkan kemampuan peserta didik secara objektif. Hal ini sesuai dengan yang dikatakan oleh Bank Dunia dalam Sedarmayanti bahwa: "Keluaran pendidikan adalah pencapaian prestasi belajar murid yang meliputi pengetahuan, keterampilan, tingkah laku dan sikap yang diukur dengan tes, hasil ujian dan sejenisnya." ${ }^{\prime 10}$ Dari pengertian di atas jelaslah alat evaluasi dalam hal ini adalah tes, merupakan suatu komponen yang cukup penting dalam kegiatan belajar mengajar agama, suatu tes yang baik akan dapat menggambarkan secara jelas, hasil yang dicapai oleh peserta didik dan sebaliknya suatu tes yang buruk akan memberikan gambaran yang tidak tepat mengenai kemampuan peserta didik sehingga hasil yang dicapai peserta didik melalui tes akan dapat menyesatkan peserta didik, pendidik, orang tua, dan berbagai pihak lain yang berkepentingan.

Berdasarkan paparan di atas maka dalam rangka memperbaiki kualitas pendidikan agama di Indonesia sehingga dapat meningkatkan kualitas sumber daya manusia, maka salah satu upaya yang perlu dilakukan adalah dengan meningkatkan motivasi belajar para peserta didik dalam belajar agama, karena "peserta didik yang memiliki motivasi yang kuat, akan banyak energi untuk melakukan kegiatan belajar" ${ }^{11}$ dan untuk meningkatkan motivasi peserta didik dalam belajar agama maka dapat dilakukan dengan membuat suatu alat evaluasi yang baik. Salah satu alat evalusi yang sering digunakan dalam kegiatan belajar mengajar adalah alat evaluasi yang berbentuk tes hasil belajar, tentunya tes hasil belajar tersebut harus disusun berdasarkan aturan-aturan penyusunan tes yang baik, sehingga tes hasil belajar tersebut akan dapat menghasilkan gambaran yang tepat dan terpercaya mengenai kemampuan peserta didik yang sesungguhnya, sehingga diharapkan dengan adanya suatu tes hasil belajar yang baik tersebut maka motivasi peserta didik dalam belajar agama dapat ditingkatkan.

Berdasarkan latar belakang di atas maka rumusan masalah dalam tulisan ini sebagai berikut: 1) Hal-hal apa saja yang harus diperhatikan dalam penyusunan sebuah tes hasil belajar yang baik? 2) Bagaimana tes hasil belajar dapat meningkatkan motivasi peserta didik dalam belajar agama? Tujuan tulisan ini yaitu untuk mengkaji hal-hal yang perlu diperhatikan dalam penyusunan tes hasil belajar yang baik, mengetahui bagaimana tes hasil belajar dapat meningkatkan motivasi peserta didik dalam belajar agama.

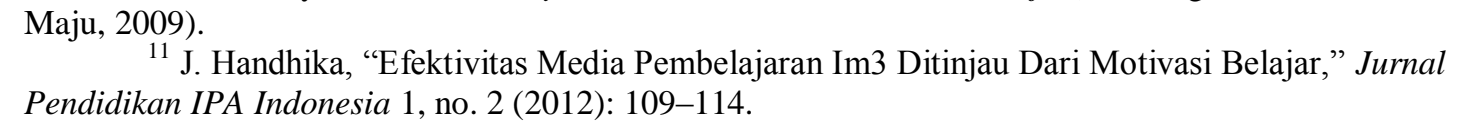
11 J. Handhika, “Efektivitas Media Pembelajaran Im3 Ditinjau Dari Motivasi Belajar,” Jurnal
Pendidikan IPA Indonesia 1, no. 2 (2012): 109-114.

${ }^{10}$ Sedarmayanti, Sumber Daya Manusia Dan Produktivitas Kerja (Bandung: Penerbit Mandar 22 - The New Perspective in Theology and Religious Studies, Vol. 1, No. 1, 2020 


\section{Metode}

Untuk mengkaji permasalahan di dalam makalah ini maka digunakan pendekatan deduktif yaitu mencari berbagai konsep atau teori-teori yang relevan yang dapat dijadikan sebagai landasan atau kerangka bagi pemecahan masalah. Hal ini dilakukan dengan membaca dan mempelajari literatur-literatur, sehingga dapat diperoleh gambaran tentang teori-teori atau konsep-konsep dari para ahli, dalam rangka memecahkan masalah yang dikemukakan.

\section{Pembahasan}

\section{Penyusunan Tes Hasil Belajar}

Sebuah tes yang baik merupakan suatu tes yang dapat memberikan informasi yang tepat dan terpercaya. Sehingga untuk dapat menghasilkan suatu tes yang baik maka terdapat beberapa hal yang harus diperhatikan dalam penyusunan sebuah tes hasil belajar, antara lain berkaitan dengan prinsip-prinsip pengukuran tes hasil belajar, tujuan dari diadakannya tes hasil belajar dan langkah-langkah penyusunan tes yang baik.

Mengenai prinsip-prinsip penyusunan tes hasil belajar Gronlund merumuskan beberapa prinsip dasar dalam pengukuran hasil belajar sebagai berikut:

1. Tes hasil belajar harus mengukur hasil belajar yang telah dibatasi secara jelas sesuai dengan tujuan instruksional.

2. Tes hasil belajar harus mengukur suatu sampel yang representatif dari hasil belajar dan dari materi yang dicakup oleh program instruksi atau pengajaran.

3. Tes hasil belajar harus berisi item-item dengan tipe yang paling cocok guna mengukur hasil belajar yang diinginkan.

4. Tes hasil belajar harus berisi item-item dengan tipe yang paling cocok guna mengukur hasil belajar yang diinginkan.

5. Tes hasil belajar harus dirancang agar cocok dengan tujuan penggunaan hasilnya.

6. Tes hasil belajar harus dibuat sereliabel mungkin dan kemudian harus ditafsirkan hasilnya dengan hati-hati.

7. Tes hasil belajar harus digunakan untuk meningkatkan belajar para siswa. ${ }^{12}$

${ }^{12}$ F. Norman Gronlund, Constructing Achievement Test Second Edition (Semarang: IKIP Semarang Press, 1985).

The New Perspective in Theology and Religious Studies, Vol. 1, No. 1, 2020 - 23 
Pada dasarnya tujuan utama yang ingin dicapai melalui pemberian tes hasil belajar yaitu untuk mengetahui sejauhmana peserta didik menguasai materi pelajaran yang diberikan, diharapkan dengan mengetahui hasil belajar peserta didik maka baik peserta didik maupun pendidik dapat mengetahui sejauhmana keberhasilan mereka dalam belajar dan mengajar, sehingga dapat diambil tindakan-tindakan yang tepat dalam rangka memperbaiki dan meningkatkan kualitas belajar peserta didik dan kualitas mengajar pendidik.

Selanjutnya dalam penyusunan tes hasil belajar, tentunya terdapat serangkaian langkah yang perlu diperhatikan sehingga tes hasil belajar tersebut dapat disusun secara benar, langkah-langkah tersebut antara lain:

1. Menentukan tujuan mengadakan tes.

2. Mengadakan pembatasan terhadap bahan yang akan diteskan.

3. Merumuskan tujuan instruksional khusus dari tiap bagian bahan.

4. Menderetkan semua Tujuan Instruksional Khusus (TIK) dalam tabel persiapan yang memuat pula aspek tingkah laku yang terkandung dalam TIK tersebut. Tabel ini digunakan untuk mengadakan identifikasi terhadap tingkah laku yang dikehendaki, agar tidak terlewati. ${ }^{13}$

Contoh :

Tabel 1. TIK dan Aspek Tingkah Laku yang Dicakup

\begin{tabular}{|l|c|c|c|c|}
\hline \multicolumn{1}{|c|}{ TIK } & Ingatan & Pemahaman & Aplikasi & Keterangan \\
\hline $\begin{array}{l}\text { 1. Siswa dapat menghormati sesa- } \\
\text { manya yang sedang beribadah. }\end{array}$ & $\sqrt{ }$ & $\sqrt{ }$ & \\
\hline $\begin{array}{l}\text { 2. Siswa dapat menjelaskan pen- } \\
\text { ciptaan alam semesta. }\end{array}$ & $\sqrt{ }$ & & \\
\hline
\end{tabular}

5. Menyusun tabel spesifikasi yang memuat pokok materi, aspek berpikir yang diukur beserta imbangan antara kedua hal tersebut.

6. Menuliskan butir-butir soal, berdasarkan atas TIK-TIK yang sudah dituliskan pada tabel TIK dan aspek tingkah laku yang dicakup. ${ }^{14}$

\footnotetext{
${ }^{13}$ Suharsimi Arikunto, Dasar-Dasar Evaluasi Pendidikan (Jakarta: Bumi Aksara, 2014).

${ }^{14}$ Ibid.
} 
Secara umum langkah-langkah penyusunan tes tersebut merupakan suatu upaya penerapan prinsip-prinsip pengukuran tes kedalam rangkaian yang sistematis sehingga suatu tes yang disusun dapat memberikan hasil yang tepat dan terpercaya, sehingga tujuan pemberian tes hasil belajar dapat dicapai.

Pada dasarnya masalah-masalah yang sering timbul dalam penyusunan tes adalah berkaitan dengan tiga hal, yaitu : Pertama, bagaimana suatu tes yang disusun dapat dengan tepat mengukur apa yang hendak diukur. Kedua, bagaimana suatu tes yang disusun dapat memberikan hasil yang dapat dipercaya. Ketiga, bagaimana suatu tes yang disusun tersebut dapat dengan mudah dilaksanakan. Secara singkat masalah yang timbul dalam penyusunan tes adalah menyangkut dua hal yaitu mutu tes dan pengadministrasian atau pelaksanaan tes.

Dalam rangka mengatasi permasalahan-permasalahan yang berkaitan dengan penyusunan tes tersebut maka kiranya terdapat beberapa hal yang dapat dilakukan. Pertama, agar suatu tes dapat dengan tepat mengukur apa yang hendak diukur, maka ada beberapa hal yang harus diperhatikan antara lain: suatu tes hendaknya disusun berdasarkan tujuan instruksional yang telah ditetapkan, perlu diusahakan agar soal-soal tes yang diberikan dapat dengan tepat mewakili materi yang telah diberikan, jenis pertanyaan tes perlu disusun dengan tepat sehingga dapat dengan tepat mengukur kemampuan peserta didik, suatu bentuk tes hendaknya dapat disusun sesuai dengan tujuan penggunaan hasilnya. Kedua, agar suatu tes dapat menghasilkan hasil yang reliabel maka dapat dilakukan dengan memperbanyak pertanyaan dan dengan perbaikan mutu setiap pertanyaan tersebut. Tes yang lebih lama pelaksanaannya memungkinkan adanya sampel tingkah laku yang lebih tepat untuk diukur, dan tes yang disusun dengan teliti akan memberikan gambaran yang lebih dapat dipercaya tentang penampilan belajar selama tes diadakan. Ketiga, agar suatu tes dapat dengan mudah dilaksanakan, maka terdapat beberapa hal yang perlu diperhatikan yaitu: suatu tes harus memuat petunjuk-petunjuk yang jelas bagaimana suatu tes tersebut dapat dikerjakan, pertanyaan dalam tes hendaknya tidak membingungkan peserta didik, tes yang disusun hendaknya dapat dengan mudah dilakukan pemeriksaannya, kemudian hendaknya suatu tes disusun dengan mempertimbangkan waktu, tenaga, dan ongkos yang tersedia. Secara singkat dapat dikatakan bahwa untuk mengatasi beberapa permasalahan dalam penyusunan tes dapat dilakukan dengan memahami prinsip-prinsip penyusunan tes yang benar.

The New Perspective in Theology and Religious Studies, Vol. 1, No. 1, 2020 - 25 


\section{Motivasi Peserta didik dalam Belajar Agama}

Menurut Morgan yang ditulis kembali oleh S. Nasution ${ }^{15}$, dikatakan bahwa manusia hidup itu memiliki berbagai kebutuhan:

\section{Kebutuhan Untuk Berbuat Sesuatu Untuk Sesuatu Aktivitas}

Hal ini bagi anak akan sangat penting, karena perbuatan itu sendiri mengandung suatu kegembiraan baginya. Sesuai dengan konsep ini, maka orang tua yang memaksa anak untuk diam di rumah saja, adalah bertentangan dengan hakikat anak. Activities in it self is a pleasure. Hal ini dapat dihubungkan dengan suatu kegiatan belajar bahwa pekerjaan atau belajar itu akan berhasil kalau disertai dengan rasa gembira.

Kebutuhan Untuk Menyenangkan Orang Lain

Banyak orang yang dalam kehidupannya memiliki motivasi untuk banyak berbuat sesuatu demi kesenangan orang lain. Harga diri seseorang dapat dinilai dari berhasil tidaknya usaha untuk memberikan kesenangan pada orang lain. Hal ini sudah barang tentu merupakan kepuasan dan kebahagiaan tersendiri bagi orang yang melakukan kegiatan tersebut. Konsep ini dapat diterapkan pada berbagai kegiatan, misalnya anak-anak itu rela bekerja atau para peserta didik itu rajin/rela belajar apabila diberikan motivasi untuk melakukan suatu kegiatan belajar untuk orang yang disukainya (misalnya bekerja, belajar demi orang tua, belajar demi seseorang calon teman hidupnya).

\section{Kebutuhan Untuk Mencapai Hasil}

Suatu pekerjaan atau kegiatan belajar itu akan berhasil baik, kalau disertai dengan "pujian". Aspek "pujian” ini merupakan dorongan bagi seseorang untuk bekerja dan belajar dengan giat. Apabila hasil pekerjaan atau usaha belajar tidak dihiraukan orang lain/pendidik atau orang tua misalnya, boleh jadi kegiatan anak menjadi berkurang. Dalam kegiatan belajar mengajar istilahnya perlu dikembangkan unsur reinforcement. Pujian atau reinforcement ini harus selalu dikaitkan dengan prestasi anak yang baik. Anak-anak harus diberi kesempatan yang seluas-luasnya untuk melakukan sesuatu dengan hasil yang optimal, sehingga ada "sense of success". Dalam kegiatan

\footnotetext{
${ }^{15}$ S Nasution, Didaktik Asas-Asas Mengajar (Jakarta: Bumi Aksara, 2011).
} 
belajar mengajar maka kegiatan ini harus dimulai dari yang mudah/sederhana dan bertahap menuju sesuatu yang semakin sulit/kompleks.

\section{Kebutuhan Untuk Mengatasi Kesulitan}

Suatu kesulitan atau hambatan, mungkin cacat, mungkin menimbulkan rasa rendah diri, namun hal ini menjadi dorongan untuk mencari kompensasi dengan usaha yang tekun dan luar biasa, sehingga tercapai kelebihan/keunggulan dalam bidang tertentu. Sikap anak terhadap kesulitan atau hambatan ini sebenarnya banyak bergantung pada keadaan dan sikap lingkungan. Sehubungan dengan itu maka peranan motivasi sangat penting dalam upaya menciptakan kondisi-kondisi tertentu yang lebih kondusif bagi mereka untuk berusaha agar memperoleh keunggulan.

Kebutuhan manusia yang senantiasa akan selalu berubah, tentunya akan memengaruhi motivasi seseorang karena motivasi selalu terkait dengan kebutuhan yang bersifat dinamis, sesuai dengan keinginan dan perhatian manusia.

Teori tentang motivasi ini lahir dan awal perkembangannya ada di kalangan para psikolog. Menurut ahli ilmu jiwa, dijelaskan bahwa dalam motivasi itu ada suatu hierarki atau tingkatan-tingkatannya, yakni dari atas ke bawah.

Dalam hal ini terdapat beberapa teori motivasi yang selalu berhubungan dengan kebutuhan:

a. Kebutuhan fisiologis, seperti lapar, haus, kebutuhan untuk istirahat dan sebagainya.

b. Kebutuhan akan keamanan (security), yakni rasa aman, bebas dari rasa takut dan kecemasan.

c. Kebutuhan akan cinta dan kasih: kasih, rasa diterima dalam suatu masyarakat atau golongan (keluarga, sekolah, kelompok).

d. Kebutuhan untuk mewujudkan diri sendiri, yakni mengembangkan bakat dengan usaha mencapai hasil dalam bidang pengetahuan, sosial, pembentukan pribadi. Dengan istilah lain, kebutuhan untuk berusaha ke arah kemandirian dan aktualisasi diri. ${ }^{16}$

Sesuai dengan kebutuhan itu Maslow menciptakan piramida hierarki kebutuhan yang lebih lengkap yang dilukiskan pada Gambar berikut:

\footnotetext{
${ }^{16}$ Ibid.
} 


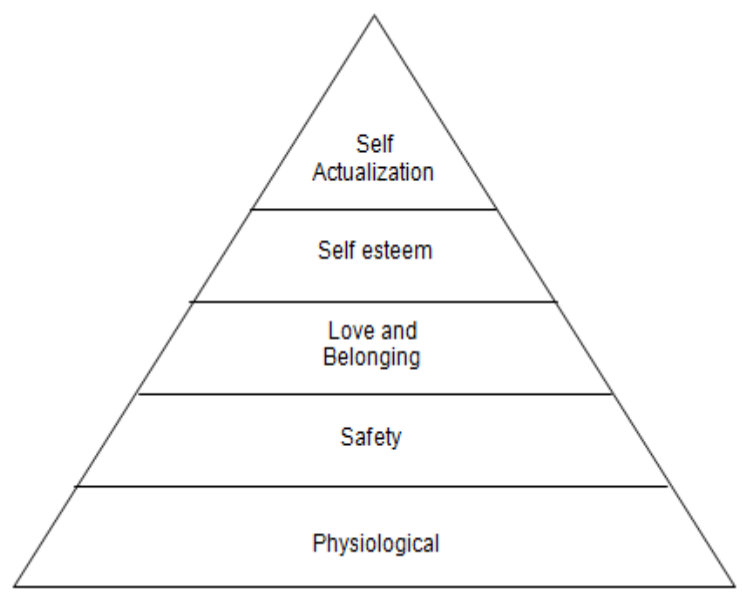

Gambar 1. Teori Kebutuhan Maslow

Perlu ditegaskan bahwa setiap tingkat di atas hanya dapat dibangkitkan apabila telah dipenuhi tingkat motivasi di bawahnya. Bila pendidik menginginkan peserta didiknya belajar dengan baik, maka harus dipenuhi tingkat yang terendah sampai yang tertinggi. Anak yang lapar, merasa tidak aman, tidak diterima sebagai anggota masyarakat kelas, guncang harga dirinya, tentu tidak akan dapat belajar secara baik. ${ }^{17}$

Selanjutnya untuk melengkapi uraian makna dan teori motivasi itu, perlu dikemukakan adanya beberapa ciri motivasi. Motivasi yang ada pada diri seseorang memiliki ciri-ciri sebagai berikut:

a. Tekun menghadapi tugas (dapat bekerja terus-menerus dalam waktu yang lama, tidak pernah berhenti sebelum selesai).

b. Ulet menghadapi kesulitan (tidak lekas putus asa). Tidak memerlukan dorongan dari luar untuk berprestasi sebaik mungkin (tidak cepat puas dengan prestasi yang telah dicapainya).

c. Menunjukkan minat terhadap bemacam-macam masalah.

d. Lebih senang bekerja mandiri.

e. Cepat bosan pada tugas-tugas yang rutin.

f. Dapat mempertahankan pendapatnya (kalau sudah yakin akan sesuatu).

g. Tidak mudah melepaskan hal-hal yang diyakini itu.

h. Senang mencari dan memecahkan masalah soal-soal. ${ }^{18}$

Di samping, jenis-jenis kebutuhan yang menjadi dasar teori motivasi, kebutuhan yang tidak kalah pentingnya adalah kebutuhan spiritual. Bambang mengemukakan

\footnotetext{
${ }^{17}$ AM Sardiman, Interaksi \& Motivasi Belajar Mengajar (Jakarta: Rajawali Press, 2011).

${ }^{18}$ Ibid.
} 
bahwa kebutuhan spiritual merupakan suatu keyakinan pendekatan, harapan dan kepercayaan pada Tuhan serta kebutuhan untuk menjalankan agama yang dianut, kebutuhan untuk dicintai dan diampuni oleh Tuhan yang seluruhnya dimiliki dan harus dipertahankan oleh seseorang sampai kapanpun agar memperoleh pertolongan, ketenangan, keselamatan, kekuatan, penghiburan serta kesembuhan. ${ }^{19}$ Menurut Kozier, spiritual merupakan salah satu kebutuhan fundamental yang dibutuhkan individu agar mampu memberikan motivasi terhadap perubahan yang lebih baik untuk mempertahankan keharmonisan dan keselarasan seseorang dengan dunia luar, dan merupakan upaya individu untuk menjawab atau mendapatkan kekuatan ketika menghadapi stres emosional, penyakit fisik, atau kematian. ${ }^{20}$ Dengan mencermati pendapat di atas, bisa dikatakan bahwa motivasi peserta didik dalam belajar agama merupakan usaha untuk memenuhi kebutuhan spiritual peserta didik. Kebutuhan spiritual ini merupakan sangat penting bagi peserta didik dalam rangka menolong dirinya ketika menghadapi masalah sekaligus membantunya untuk berperilaku selaras dengan dunia di mana dirinya tinggal. Kebutuhan spiritual ini penting karena memiliki fungsi baik ke dalam diri peserta didik maupun fungsi ke luar, dalam hidup bermasyarakat.

Kemudian Pasal 2 Peraturan Pemerintah No. 55 Tahun 2007 mengemukakan tujuan pendidikan agama adalah untuk mengembangkan kemampuan peserta didik dalam memahami, menghayati dan mengamalkan nilai-nilai agama yang menyerasikan penguasaannya dalam IPTEK dan seni. ${ }^{21}$ Sehingga dapat dikatakan bahwa motivasi peserta didik dalam belajar agama di sekolah ditujukan pertama kali untuk memenuhi kebutuhan spiritual peserta didik, setelah kebutuhan spiritual peserta didik terpenuhi maka selanjutnya peserta didik perlu didorong untuk mengamalkannya dalam kehidupan sehari-hari bermasyarakat. Tugas pendidik mata pelajaran agama dalam hal ini adalah mengembangkan kebutuhan spiritual peserta didik melalui pendidikan agama, kemudian mendorongnya untuk mengaplikasikan dalam kehidupan peserta didik. Meski demikian, penelitian yang dilakukan Rizki Permatasari menemukan terdapat

\footnotetext{
${ }^{19}$ Firda Ayu Wahyuni, "Hubungan Pemenuhan Kebutuhan Spiritual Dengan Motivasi Kesembuhan Pasien Rawat Inap Di Rumah Sakit Ibnu Sina YW-UMI Makassar" (UIN Alauddin Makassar, 2014).

${ }^{20}$ Elva Sujana, Sari Fatimah, and Nur Oktavia Hidayati, "Kebutuhan Spiritual Keluarga Dengan Anak Penderita Penyakit Kronis," Jurnal Pendidikan Keperawatan Indonesia 3, no. 1 (2017): 47.

${ }^{21}$ Indonesia, Peraturan Pemerintah Nomor 55 Tahun 2007 Tentang Pendidikan Agama Dan Pendidikan Keagamaan.
}

The New Perspective in Theology and Religious Studies, Vol. 1, No. 1, 2020 - 29 
faktor-faktor penyebab menurunnya motivasi peserta didik dalam belajar agama, faktor internal berupa kurangnya perhatian peserta didik pada saat mengikuti pelajaran agama, sementara faktor eksternal meliputi kurangnya penggunaan metode yang bervariasi, kurangnya media dan sumber belajar, kurangnya penegakan disiplin sekolah dan lingkungan yang mendukung. ${ }^{22}$ Faktor-faktor yang menjadi penghambat tumbuhnya motivasi belajar peserta didik dalam belajar agama ini, tentunya perlu mendapatkan perhatian guru agama dalam mengajarkan pendidikan agama kepada peserta didik sehingga dapat diantisipasi.

\section{Tes Hasil Belajar Membantu Meningkatkan Motivasi Peserta didik dalam Belajar}

\section{Agama}

Tes yang dilaksanakan secara berkala akan dapat memotivasi peserta didik dalam belajar agama dengan menyediakan tujuan-tujuan belajar jangka pendek yang mengarahkan cara belajar dengan menjelaskan kepada peserta didik hasil belajar yang diharapkan, dan menyediakan umpan balik baginya tentang kemajuan belajar yang dicapainya. Antisipasi mengenai akan adanya tes memperbesar kegiatan belajar dan sifat serta corak tes yang ditunggu-tunggu menyalurkan dan mengarahkan corak belajar yang dilakukan. Walaupun pengaruh tes serupa ini kadang-kadang dianggap tidak baik, misalnya jika tes hanya mengukur hasil ingatan mengenai fakta, pengaruh demikian tidak harus dianggap negatif. Sumbangan tes itu terhadap perbaikan belajar agama akan sangat bergantung pada seberapa tes itu dapat mencerminkan hasil belajar yang diharapkan dapat dicapai oleh peserta didik dan pada cara pengajar menggunakan hasil tes tersebut. Jika tes itu menekankan pada "aplikasi prinsip-prinsip" seperti yang dilakukan dalam pengajaran agama maka dapatlah diharapkan bahwa peserta didikpeserta didik akan mengarahkan usahanya belajar pada cara mengaplikasikan prinsipprinsip. Kemudian jika hasil tes secepat-cepatnya diumumkan kepada peserta didikpeserta didik, maka umpan balik tentang kemahiran dan kelemahan mereka mengaplikasikan prinsip-prinsip akan lebih menjelaskan hakikat tujuan belajar agama dan menunjukkan perubahan yang diperlukan untuk mencapai mutu penampilan yang efektif. "Individu dikatakan belajar atau tidak sangat bergantung kepada kebutuhan dan

\footnotetext{
${ }^{22}$ Permatasari, "Faktor-Faktor Penyebab Rendahnya Motivasi Belajar Peserta Didik Pada Mata Pelajaran Pendidikan Agama Islam Di SMP Guna Dharma Bandar Lampung."
}

30 - The New Perspective in Theology and Religious Studies, Vol. 1, No. 1, 2020 
motivasinya."23 Jadi tes yang disusun dengan baik itu akan memberikan motivasi kepada peserta didik agar belajar untuk mencapai tujuan pengajaran dengan menimbulkan semangat belajar agama yang lebih tinggi, dengan lebih mengarahkan mereka pada tujuan belajar yang diinginkan dan dengan menyediakan usaha mencapai pengetahuan yang segera tentang hasil tes. Hal ini sesuai dengan fungsi motivasi dalam belajar yang bertujuan menstimulasi dan memfasilitasi aktivitas belajar. ${ }^{24}$

Masalah yang seringkali ditemukan berkaitan dengan usaha pemberian tes untuk meningkatkan motivasi peserta didik dalam belajar agama adalah: Pertama, kurang dikomunikasikannya manfaat diberikannya tes kepada peserta didik akibatnya para peserta didik tidak menganggap bahwa tes yang diberikan tersebut sebagai sesuatu yang dapat membantu mereka, namun sebaliknya mereka menganggap bahwa tes yang dilaksanakan justru dianggap hanya sebatas rutinitas yang membebani mereka selama belajar agama. Untuk mengatasi hal ini maka perlu dilakukan penekanan kepada peserta didik mengenai arti penting tes tersebut bagi mereka, para peserta didik perlu memahami bahwa tujuan utama diberikannya tes adalah untuk membantu mereka dalam belajar, sehingga apabila peserta didik dapat memahami bahwa tes yang diberikan kepada mereka adalah merupakan sarana yang menolong mereka maka fungsi tes sebagai motivator dan pengarah dalam belajar agama akan tercapai. Kedua, berkaitan dengan masalah pelaksanaan tes, sering kali pelaksanaan tes yang ditunda-tunda akan dapat mengurangi motivasi peserta didik dalam belajar agama karena dampak dari penundaan tes ini adalah timbulnya rasa kecewa bagi peserta didik yang memang telah benar-benar belajar untuk menghadapi tes, untuk mengatasi hal ini maka tentunya pihak pendidik mata pelajaran agama harus berusaha agar pelaksanaan tes dapat dilaksanakan tepat pada waktunya. Ketiga, berkaitan dengan umpan balik dari hasil tes tersebut, sering kali pendidik mata pelajaran agama tidak dapat memberitahukan hasil tes yang dikerjakan peserta didik dengan segera, sehingga pada akhirnya peserta didik mengalami penurunan motivasi belajar karena peserta didik tersebut tidak dapat mengetahui dengan segera sejauhmana ia telah berhasil mengerjakan tes tersebut, hal ini sesuai dengan yang dikatakan Saifuddin Azwar bahwa: "Hasil tes yang baik dan segera

\footnotetext{
${ }^{23}$ Keke Aritonang, "Minat Dan Motivasi Dalam Meningkatkan Hasil Belajar Siswa," Jurnal Pendidikan Penabur, no. 10 (2008): 11-21.

${ }^{24}$ Puja Mondal, "Importance of Motivation in Learning (657 Words)," accessed November 4, 2019, http://www.yourarticlelibrary.com/motivation/importance-of-motivation-in-learning-657words/5998.
}

The New Perspective in Theology and Religious Studies, Vol. 1, No. 1, 2020 - 31 
diketahui oleh peserta didik akan menjadi pengalaman yang menyenangkan yang akan memperkuat untuk belajar kembali," 25 untuk mengatasi hal ini maka tentunya diperlukan usaha dari pendidik mata pelajaran agama agar dapat memberitahukan hasil tes tersebut dengan segera kepada peserta didik. Keempat, berkaitan dengan pandangan bahwa motivator ekstrinsik seperti tes dianggap kurang baik dibandingkan motivator instrinsik. Sebagaimana teori psikologi menyatakan bahwa, motivator ekstrinsik biasanya tidak dapat bertahan lama dan efeknya segera hilang bilamana tujuan telah tercapai. Karena itu motivator instrinsik dianggap lebih baik dan lebih tahan lama. Untuk meluruskan pandangan yang menganggap bahwa motivasi ekstrinsik seperti tes dianggap kurang baik, maka diperlukan pemahaman yang lebih dalam berkaitan dengan tujuan belajar, dimana dalam masalah belajar menurut Ebel (1979) sebagaimana dikutip Saifuddin Azwar bahwa, "Tidaklah penting untuk membedakan mana yang didorong oleh motivasi instrinsik dan mana yang didorong oleh motivasi ekstrinsik karena yang pokok adalah tercapainya tujuan belajar itu sendiri." ${ }^{26}$ Sehingga apabila belajar agama dapat terjadi dengan memberikan motivasi ekstrinsik, maka justru motivasi inilah yang perlu dimanipulasi dan digunakan sehingga memberikan efek maksimal terhadap usaha dalam belajar. Apalagi kalau disadari bahwa pemberian motivasi ekstrinsik adalah jauh lebih mudah daripada membangun motivasi instrinsik dalam diri seseorang.

Secara umum dapatlah dikatakan bahwa untuk meningkatkan motivasi peserta didik dalam belajar agama melalui pemberian tes maka diperlukan usaha lebih dari pihak pendidik mata pelajaran agama untuk merencanakan, menyusun, melaksanakan dan mengevaluasi pemberian tes hasil belajar tersebut serta memahami pentingnya peranan tes dalam meningkatkan motivasi peserta didik dalam belajar agama.

\section{Kesimpulan}

Berdasarkan rumusan masalah dalam penulisan makalah ini maka ditarik simpulan sebagai berikut. Pertama, dalam penyusunan sebuah tes hasil belajar terdapat beberapa hal yang perlu diperhatikan yaitu berkaitan dengan prinsip-prinsip penyusunan tes hasil belajar, tujuan penyusunan tes hasil belajar dan langkah-langkah penyusunan tes hasil belajar, sehingga dengan memperhatikan hal-hal tersebut maka diharapkan tes

\footnotetext{
${ }^{25}$ Saifuddin Azwar, Test Prestasi Fungsi Dan Pengembangan Pengukuran Prestasi Belajar (Yogyakarta: Pustaka Pelajar, 2012).

${ }^{26}$ Ibid.
}

32 - The New Perspective in Theology and Religious Studies, Vol. 1, No. 1, 2020 
hasil belajar yang disusun dapat dengan tepat mengukur apa yang hendak diukur, dapat memberikan hasil yang terpercaya dan pengadministrasiannya dapat dilakukan dengan mudah. Kedua, tes yang dilaksanakan secara berkala akan dapat memotivasi peserta didik dalam belajar agama dengan menyediakan tujuan-tujuan belajar jangka pendek yang mengarahkan cara belajar dengan menjelaskan kepada peserta didik hasil belajar yang diharapkan, dan menyediakan umpan balik baginya tentang kemajuan belajar yang dicapainya. Pemahaman peserta didik terhadap tujuan pemberian tes akan dapat menjadi sarana yang menolong mereka sehingga fungsi tes sebagai motivator dan pengarah dalam belajar akan tercapai. Pelaksanaan tes yang tepat waktu dan hasil yang segera dapat diketahui peserta didik akan dapat mendorong peserta didik untuk belajar kembali.Tes sebagai motivator ekstrinsik memiliki peranan yang cukup penting dalam meningkatkan motivasi peserta didik dalam belajar agama. Untuk meningkatkan motivasi peserta didik dalam belajar agama maka diperlukan usaha lebih dari pendidik untuk merencanakan, menyusun, melaksanakan, dan mengevaluasi pemberian tes tersebut serta pemahaman yang tepat terhadap peranan tes dalam meningkatkan motivasi peserta didik dalam belajar agama.

\section{Rujukan}

Arikunto, Suharsimi. Dasar-Dasar Evaluasi Pendidikan. Jakarta: Bumi Aksara, 2014. Aritonang, Keke. "Minat Dan Motivasi Dalam Meningkatkan Hasil Belajar Siswa." Jurnal Pendidikan Penabur, no. 10 (2008): 11-21.

Asrori, Achmad. "CONTEMPORARY RELIGIOUS EDUCATION MODEL ON THE CHALLENGE OF INDONESIAN MULTICULTURALISM.” JOURNAL OF INDONESIAN ISLAM 10 (2016): 2.

Azwar, Saifuddin. Test Prestasi Fungsi Dan Pengembangan Pengukuran Prestasi Belajar. Yogyakarta: Pustaka Pelajar, 2012.

Gronlund, F. Norman. Constructing Achievement Test Second Edition. Semarang: IKIP Semarang Press, 1985.

Handhika, J. "Efektivitas Media Pembelajaran Im3 Ditinjau Dari Motivasi Belajar." Jurnal Pendidikan IPA Indonesia 1, no. 2 (2012): 109-114.

Indonesia. Laporan Tahunan Kehidupan Keagamaan 2018. Jakarta, 2018.

The New Perspective in Theology and Religious Studies, Vol. 1, No. 1, 2020 - 33 
_. Peraturan Pemerintah Nomor 55 Tahun 2007 Tentang Pendidikan Agama Dan Pendidikan Keagamaan, 2007.

—. Undang-Undang Republik Indonesia Nomor 20 Tahun 2003 Tentang Sistem

Pendidikan Nasional, 2003.

Mondal, Puja. "Importance of Motivation in Learning (657 Words)." Accessed

November 4, 2019. http://www.yourarticlelibrary.com/motivation/importanceof-motivation-in-learning-657-words/5998.

Nasution, S. Didaktik Asas-Asas Mengajar. Jakarta: Bumi Aksara, 2011.

Permatasari, Rizki. "Faktor-Faktor Penyebab Rendahnya Motivasi Belajar Peserta Didik Pada Mata Pelajaran Pendidikan Agama Islam Di SMP Guna Dharma Bandar Lampung.” UIN Raden Intan Bandar Lampung, 2018.

Sardiman, AM. Interaksi \& Motivasi Belajar Mengajar. Jakarta: Rajawali Press, 2011. Sedarmayanti. Sumber Daya Manusia Dan Produktivitas Kerja. Bandung: Penerbit Mandar Maju, 2009.

Sujana, Elva, Sari Fatimah, and Nur Oktavia Hidayati. "Kebutuhan Spiritual Keluarga Dengan Anak Penderita Penyakit Kronis.” Jurnal Pendidikan Keperawatan Indonesia 3, no. 1 (2017): 47.

Suprapto, Rohmat, and S Ag. "Deradikalisasi Agama Melalui Pendidikan MultikulturalInklusivisme" 15, no. 2 (2011): 89-105.

Ulya, Iik Faiqotul, and Riana Irawati. "Peningkatan Kemampuan Koneksi Matematis Dan Motivasi Belajar Siswa Menggunakan Pendekatan Kontekstual.” Pena Ilmiah 1, no. 1 (2016): 121-130.

Wahyuni, Firda Ayu. "Hubungan Pemenuhan Kebutuhan Spiritual Dengan Motivasi Kesembuhan Pasien Rawat Inap Di Rumah Sakit Ibnu Sina YW-UMI Makassar." UIN Alauddin Makassar, 2014.

Wulandari, Bekti, and Herman Dwi Surjono. "Pengaruh Problem-Based Learning Terhadap Hasil Belajar Ditinjau Dari Motivasi Belajar PLC Di SMK.” Jurnal Pendidikan Vokasi 3, no. 2 (2013): 178-191. 